\title{
PERBEDAAN STATUS GIZI PADA ANAK DENGAN PENYAKIT JANTUNG BAWAAN SIANOTIK DAN NON SIANOTIK
}

\author{
${ }^{1}$ Meyrina E. Sondakh \\ ${ }^{2}$ Erling D. Kaunang \\ ${ }^{2}$ Novie H. Rampengan
}

\author{
${ }^{1}$ Kandidat Skripisi Fakultas Kedokteran Universitas Sam Ratulangi Manado \\ ${ }^{2}$ Staf Bagian Ilmu Kesehatan Anak Fakultas Kedokteran Universitas Sam Ratulangi Manado \\ Email: meyrina.angel@gmail.com
}

\begin{abstract}
Congenital Heart Disease (CHD) is a disorder that is commonly found. The incidence of CHD in the world is 8-10 among 1,000 births. Although children with mild or moderate CHD usually have normal growth and development, the presence of CHD can result in physical growth retardation. This study aimed to obtain the difference of nutritional status among children with cyanotic and non-cyanotic CHD. This study was a retrospective analytical study with a cross sectional design. This study was conducted at the Child Health Department Prof. Dr. R. D. Kandou Manado. Data of children treated with CHD from 20092014 included age, gender, weight, height, and nutritional status. Data were analyzed with Chi-Square test. Of 55 samples, there were 34 boys and 21 girls. The results showed that the most suffered CHD was ventricular septal defect. There were $54.5 \%$ of patients with good enough nutrition, $25.5 \%$ with malnutrition, and $16.4 \%$ with severe malnutrition. The ChiSquare test obtained a $P$-value of $0.464(>0.050)$ which indicated that there was no difference in nutritional status among children with cyanotic and non-cyanotic CHD. Conclusion: According to the study there was no difference in nutritional status between cyanotic and noncyanotic congenital heart disease.
\end{abstract}

Keywords:nutritional status, congenital heart disease, cyanotic, non-cyanotic

\begin{abstract}
Abstrak: Penyakit Jantung Bawaan (PJB) merupakan kelainan yang cukup banyak ditemukan. Insidensi PJB di dunia 8-10 di antara 1.000 kelahiran. Anak dengan PJB yang tidak begitu parah biasanya memiliki pertumbuhan dan perkembangan yang normal, tetapi adanya PJB dapat mengakibatkan hambatan pertumbuhan jasmani penderita. Penelitian ini bertujuan untuk mengetahui perbedaan status gizi pada anak dengan PJB sianotik dan non sianotik. Penelitian ini menggunakan metode retrospektif analitik dengan desain potong lintang dan dilaksanakan di Bagian Ilmu Kesehatan Anak BLU RSUP Prof. Dr. R. D. Kandou Manado. Data diambil dari semua anak yang dirawat dengan PJB tahun 2009-2014 meliputi umur, jenis kelamin, berat badan, tinggi badan, dan status gizi anak. Analisis data dilakukan dengan uji Chi-Square. Jumlah sampel 55 anak terdiri dari 34 lelaki dan 21 perempuan. Jenis PJB terbanyak yang diderita ialah ventricular septal defect. Penderita dengan gizi cukup 54,5\%; gizi kurang 25,5\%; dan gizi buruk 16,4\%. Dengan uji Chi-Square, didapatkan nilai $P$ 0,464 $(<0,050)$ yang menunjukkan tidak terdapat perbedaan status gizi antara anak dengan PJB sianotik dan non sianotik. Simpulan: Tidak terdapat perbedaan status gizi antara penyakit jantung bawaan sianotik dan non sianotik.
\end{abstract}

Kata kunci: status gizi, penyakit jantung bawaan, sianotik, nonsianotik

Penyakit Jantung Bawaan (PJB) merupakan kelainan yang cukup banyak ditemukan.
Insidensi PJB di dunia adalah 8-10 di antara 1.000 kelahiran. Insidensi ini hampir 
sama antara satu negara dan negara yang lain. ${ }^{1,2} \mathrm{Di}$ Indonesia belum terdapat angka yang pasti, namun penelitian di RS. Dr. Sutomo pada tahun 2004-2006 sudah mendapatkan angka kematian yang tinggi dari pasien PJB setiap tahunnya, berturutturut $11,64 \%, 11,35 \%$, dan $13,44 \%$. $^{1,2}$

Status gizi seseorang pada dasarnya merupakan keadaan kesehatan orang tersebut sebagai refleksi dari konsumsi pangan serta penggunaannya oleh tubuh. Walaupun anak dengan PJB yang tidak begitu parah biasanya memiliki pertumbuhan dan perkembangan yang normal, tetapi dengan adanya PJB dapat mengakibatkan hambatan pertumbuhan jasmani penderita. $^{3}$

Mekanisme terjadinya gagal tumbuh pada pasien PJB disebabkan oleh asupan kalori yang tidak adekuat, gangguan pencernaan makanan (malabsorbsi), dan pengaruh hormon pertumbuhan. ${ }^{4}$

\section{PENYAKIT JANTUNG BAWAAN}

Kata "bawaan" dalam penyakit jantung bawaan (PJB) berarti kelainan pada jantung tersebut sudah terjadi sebelum anak dilahirkan. ${ }^{5}$ Mitchell dkk mendefinisikan PJB sebagai abnormalitas struktur makroskopis jantung atau pembuluh darah besar intratoraks yang mempunyai fungsi pasti atau potensial yang berarti. Sekitar 2 dari 4\% kasus PJB dihubungkan dengan lingkungan atau kelainan itu yang merugikan dan pengaruh teratogenik, termasuk DM dan atau infeksi. ${ }^{6}$ PJB secara garis besar dapat dibagi menjadi penyakit jantung bawaan sianotik dan non sianotik. PJB sianotik dapat dibagi atas: ${ }^{7}$

Aliran darah ke paru berkurang
a. Tetralogi Fallot
b. Atresia pulmonal dengan defek septum ventrikel
c. Atresia pulmonal dengan septum ventrikel utuh
d. Atresia trikuspid
e. Anomali Ebstein
Aliran darah paru bertambah
a. Transposisi arteri besar
b. Trunkus arteriosus
c. Ventrikel tunggal
d. Anomali total dreinase vena pulmonalis

PJB non sianotik dapat dibagi atas: ${ }^{8}$

Pirau kiri ke kanan

a. Defek septum ventrikel

b. Dafek septum atrium

c. Defek septum atrioventrikularis

d. Duktrus arteriosus persisten

Tanpa pirau

a. Stenosis pulmonal

b. Stenosis aorta

c. Koarktasio aorta

\section{STATUS GIZI}

Status gizi adalah keadaan tubuh sebagai akibat konsumsi makanan dan penggunaan zat-zat gizi. Status gizi ini menjadi penting karena merupakan salah satu faktor risiko untuk terjadinya kesakitan dan kematian. ${ }^{9}$

\section{Penilaian Status Gizi}

1. Berat Badan

Berat badan dipakai sebagai indikator terbaik saat ini untuk mengetahui keadaan gizi dan tumbuh kembang anak, sensitif terhadap perubahan sedikit saja, pengukuran objektif dan dapat diulangi, dapat digunakan timbangan apa saja yang relatif murah, mudah dan tidak memerlukan banyak waktu. $^{10}$

2. Panjang atau Tinggi badan

Pengukuran tinggi badan diperlukan sebagai parameter status gizi berdasarkan berat badan terhadap tinggi badan. ${ }^{11}$

3. Berat badan menurut umur $(\mathrm{BB} / \mathrm{U})$

Sifat berat badan yang labil, maka indeks $\mathrm{BB} / \mathrm{U}$ lebih menggambarkan status gizi seseorang pada saat ini. ${ }^{11}$

4. Berat Badan menurut tinggi badan (BB/TB)

Indeks BB/TB dapat memberikan gambaran proporsi berat badan relatif terhadap tinggi badan. ${ }^{11}$ Untuk anak umur diatas 6 tahun IDAI merekomendasikan untuk menggunakan kurva pertumbuhan CDC 2000. Kurva pertumbuhan CDC 2000 merupakan revisi dari kurva 
pertumbuhan NCHS (National Center for Health Statistics) tahun 1977. Kurva CDC digunakan sebagai "referensi" pertumbuhan yang menggambarkan pertumbuhan anak pada tempat dan waktu tertentu. ${ }^{12}$ Untuk anak 0-5 tahun, IDAI telah menetapkan skrining pertumbuhan anak dengan umur sampai 5 tahun dapat menggunakan kurva pertumbuhan WHO. ${ }^{13}$

\section{PENGARUH PENYAKIT JANTUNG BAWAAN PADA STATUS GIZI ANAK}

Anak dengan PJB yang tidak begitu parah biasanya memiliki pertumbuhan dan perkembangan yang normal, ${ }^{3}$ tetapi dengan adanya PJB dapat mengakibatkan hambatan pertumbuhan jasmani penderita. Secara fisis, yang terhambat adalah berat badan dari pada tinggi badan. Berat badan penderita tidak jarang ada di bawah persentil 3, sedangkan tinggi badan masih normal atau sedikit dibawah normal. ${ }^{14}$ Mekanisme terjadinya gagal tumbuh pada penderita PJB disebabkan oleh asupan kalori yang tidak adekuat, gangguan pencernaan makanan (malabsorbsi), dan pengaruh hormon pertumbuhan.

\section{METODE PENELITIAN}

Penelitian ini merupakan penelitian cross sectional secara retrospektif analitik. Subjek penelitian ialah semua anak yang didiagnosis menderita PJB yang di rawat di Bagian Ilmu Kesehatan Anak BLU RSUP Prof. Dr. R. D. Kandou Manado. Data yang diambil ialah semua anak yang dirawat dengan PJB tahun 2009-2014, yang meliputi umur, jenis kelamin, berat badan, tinggi badan dan status gizi anak. Analisis data dilakukan dengan uji Chi-Square.

\section{HASIL DAN BAHASAN}

Dari penelitian yang telah dilakukan selama bulan November - Desember 2014, didapatkan 55 penderita PJB yang di rawat di Bagian Ilmu Kesehatan Anak BLU RSUP Prof. Dr. R. D. Kandou Manado periode 2009-2014 yang sesuai dengan kriteria inklusi yang terdiri dari 34 anak berjenis kelamin lelaki dan 21 anak berjenis kelamin perempuan.

Distribusi umur penderita terbanyak $<5$ tahun. Distribusi PJB jenis VSD yang terbanyak $(34,5 \%)$ diikuti oleh jenis ASD (29,1\%). Distribusi penderita PJB ditemukan lebih banyak mengalami gizi cukup.

Distribusi jenis PJB sianotik dan non sianotik berdasarkan status gizi pada anak yang di rawat di Bagian Ilmu Kesehatan Anak BLU RSUP Prof. Dr. R. D. Kandou Manado periode 2009-2014 menunjukkan $P$ 0,464 ( $>0,050)$ yang menunjukkan tidak terdapat perbedaan status gizi antara anak dengan penyakit jantung bawaan dianotik dan non sianotik.

\section{SIMPULAN}

Berdasarkan hasil penelitian dan bahasan dapat disimpulkan bahwa tidak terdapat perbedaan status gizi antara penyakit jantung bawaan sianotik dan non sianotik.

\section{SARAN}

1. Perlu dilakukan penelitian untuk mengetahui faktor-faktor apa yang berperan pada status gizi anak dengan PJB.

2. Status gizi anak dengan PJB harus diperhatikan, baik oleh orang tua pasien maupun oleh petugas medis. Dengan status gizi yang baik, maka anak tersebut dapat dikatakan sehat.

3. Dilakukan penyuluhan mengenai pentingnya kecukupan gizi kepada orang tua yang mempunyai anak dengan PJB.

\section{DAFTAR PUSTAKA}

1. Rahayuningsih SE. Tatalaksana penyakit jantung bawaan sianotik. Bandung: Pustaka Unpad, 2014.

2. Cahyono A, Rachman MA. Distribusi kematian penyakit jantung bawaan di instalasi rawat inap anak rumah sakit Dokter Soetomo tahun 2004,2005 dan 2006. Jurnal Kardiologi Indonesia. 2007:280-4.

3. Rosenthal A. Nutritional consideration in the prognosis and treatment of children with congenital heart disease. In: 
Suskind RM, Suskind MM, editors. Textbook of Pediatric Nutrition (Edisi ke-2). New York: Raven Press, 1992.

4. Sukardi R. 2014. Pertumbuhan dan nutrisi pada anak dengan penyakit jantung bawaan. Available from: http://www.heartcenter.co.id/listartikel/74-nutrisianak.html

5. Rachmat J. 2015. Apa yang disebut penyakit janutng bawaan (PJB)?. Available from: http://www.heartcenter.co.id/listartikel/76-mengenai-pjb.html

6. Berustein D. Epidemiologi penyakit jantung kongenital. Ilmu Kesehatan Anak Nelson (Edisi ke-15). Jakarta: EGC, 1999; p. 1572.

7. Prasodo AM. Penyakit jantung bawaan sianotik. In: Sastroasmoro S, Madiyono B, editors. Buku Ajar Kardiologi Anak. Jakarta: Bina Rupa Aksara, 1994; h. 234-78.

8. Soeroso S, Sastrosoebroto H. Penyakit jantung bawaan non sianotik. In: Sastroasmoro S, Madiyono B, editors. Buku Ajar Kardiologi Anak. Jakarta: Binarupa Aksara, 1994; p.191-233.

9. Sjarif DR, Nasar SS, Devaera Y, Tanjung C. 2011. Rekomendasi ikatan dokter anak indonesia. Available from: https://www.google.co.id/url?sa=t\&rct $=\mathrm{j} \& \mathrm{q}=\&$ esrc $=\mathrm{s} \&$ source $=$ web $\& \mathrm{~cd}=2 \& \mathrm{c}$ ad=rja\&uact $=8 \&$ ved $=0 C C M Q F j A B \& u$ rl=http\%3A\%2F\%2Fidai.or.id\%2Fwpcontent\%2Fuploads\%2F2013\%2F02\% 2FRekomendasi-IDAI_Asuhan-NutrisiPediatrik.pdf\&ei=j2YkVI3rCZOQuAS k5oD4CA\&usg=AFQjCNG416ExzQf1 Tb8uIrRSqGD27O9rGw\&sig2=9ceEF LhnWs9g2oBSzAHt0Q\&bvm=bv.7624 7554,d.c2E

10.Irianto DP. Panduan Gizi Lengkap Keluarga dan Olahragawan. Yogyakarta: Penerbit Andi, 2007.

11.Gibson RS. Anthropometric Assessment of Body Size. Priciple of Nutritional Assessment (2nd ed). Oxford: Oxford University Press, 2005.

12.IDAI. 2013. Kurva pertumbuhan CDC 2000 lengkap. Available from: http://idai.or.id/professionalresources/growth-chart/cdc-modified21-april-2001.html

13.IDAI. 2013. Kurva pertumbuhan WHO. 2013 Mey 13. Available from: http://idai.or.id/professionalresources/growth-chart/kurvapertumbuhan-who.html

14.Prosedur diagnostik kardiologi. In: Hassan R, Alatas H, editors. Buku Kuliah Ilmu Kesehatan Anak. Jakarta: Bagian Ilmu Kesehatan Anak Fakultas Kedokteran UI, 2007; p. 663. 